\title{
„PATRZĘ Na ZNISZCZENIE, Co ŚWIĘCI SWE DZIEeo, LECZ PRZECIEŻ NIC W MYM SERCU NIE POSZŁO NA MARNE" — POETYCKIE RETROSPEKCJE JaNA LECHONIA
}

\author{
Cóż ja jestem? Lišć tylko, liść, co z drzewa leci. \\ Com czynił — wszystko było pisane na wodzie. \\ Liść jestem, co spadł z drzewa w dalekim ogrodzie, \\ Wiatr niesie go aleją, w której księżyc świeci. \\ Jednego pragnę dzisiaj: was, zimne powiewy! \\ Więc nieś mnie, wietrze chłodny, nie pytając po co, \\ Pomiędzy stare ścieżki, zapomniane krzewy, \\ Które wszystkie rozpoznam i odnajdę nocą. \\ W ostatniej woni lata, w powiewie jesieni \\ Niech padnę pod strzaskany ganek kolumnowy, \\ By ujrzeć te, com widział, podniesione głowy \\ Wśród teraz pochylonych, zamyślonych cieni. \\ Uciszaj, srebrna nocy, całą ziemię śpiewną! \\ A ja padnę na trawę wilgotną od rosy, \\ Lub będę muskał cicho niegdyś złote włosy, \\ Których dziś już koloru nie poznałbym pewno ${ }^{1}$.
}

Wiersz Nokturn, zamieszczony w tomie Aria z Kurantem, powstałym w ostatnim okresie życia Jana Lechonia, w czasie jego nowojorskiej emigracji, oddaje doskonale nastroje duszy romantyka z zapamiętaniem spoglądającego w przeszłość. Umiłowanie tego, co było, jest w biografii Lechonia kluczowe — z tego uczucia zrodził się literacki geniusz, ono przyczyniło się do jego tragicznego końca.

Lechoń pierwszy tomik wierszy, zatytułowany $N a$ złotym polu, wydał w wieku 13 lat. Zaskakiwał on dojrzałością i głębią. Młody poeta sięgał, co prawda, po znane

\footnotetext{
"Monika Urbańska - (rocznik 1978) historyk literatury, edytor, pracownik Uniwersytetu Łódzkiego, autorka książek: Utwory prozatorskie na łamach „Zabaw Przyjemnych i Pożytecznych” — Wybór. Edycja krytyczna ze wstępem, Łódź 2006; „Udawać do końca” — „Dziennik” Jana Lechonia jako świadectwo, Łódź 2010; Anna Mostowska, Powieści. Listy, Łódź 2014 oraz wielu artykułów poświęconych zagadnieniom edytorskim i tematyce filozoficznej (zwłaszcza miłości i śmierci), podejmujących analizę i interpretację dzieł literackich ze szczególnym uwzględnieniem tekstów II połowy XIX i XX wieku.

${ }^{1}$ J. Lechoń, Nokturn, [w:] tenże, Poezje, oprac. R. Loth, Wrocław 1990, s. 91. Wszystkie cytaty poetyckie podawane będą na podstawie tego wydania.
} 
motywy dekadenckiego smutku i zwątpienia, jednak zainteresowanie ucznia szkoły podstawowej topiką przemijalności i egzystencjalnego smutku nie było wówczas, ani teraz nie jest, typowe. Lechoń dorastał w domu inteligenckim, jego ojciec poza pracą zawodową prowadził działalność filantropijna, matka zaś domową szkołę. Serafinowiczowie kupowali i wypożyczali książki, swych trzech synów wychowując w szacunku dla literatury i kultury. Leszek był szczególnie blisko matki, nosząc w sobie nie tylko pokrewieństwo stanów wewnętrznych, skłonności do depresji i neurastenii, ale także udarzające podobieństwo zewnętrzne do niej. Po latach, w swym dzienniku wielokrotnie utrzymywał, że matka odcisnęła na jego psychice znamienne w skutkach piętno, wychowując go na ,drugiego Słowackiego":

Co wypada, a co nie wypada. - Była to jedna z najważniejszych spraw mej młodości, nawet mego dzieciństwa. Moi rodzice byli ludzie skromni, po prostu bardzo moralni, bez hipokryzji, tylko z polskim patosem. Co wypada - było to też dla mnie ciągłe przymierzanie się do jakiegoś nieokreślonego ideału, może nawet bardziej polskiego niż po prostu ludzkiego. Gdzieś w podświadomości czułem się Słowackim, którym chciała mnie mieć moja Matka. Właściwie więc — myślałem sobie, czy to wypada Słowackiemu, czy Słowacki mógłby tak postąpić².

Rok 1920 był w życiu Lechonia znamienny — wydanie Karmazynowego poematu i przyjęcie go przez krytykę jak literackiego objawienia stulecia odbiło się na całym życiu młodego pisarza. Ludwik Morstin po latach wpominał:

[...] Wielkie wrażenie zrobił na mnie jego debiut poetycki, ale nie tylko na mnie. Jak to się dzieje — dziwił się jeden z wytrawnych krytyków - że żaden z młodych poetów, nie wyłączając Słowackiego, nie zaczynał swojej kariery literackiej od takich fenomenalnych utworów jak Lechonia. Mochancki, Karmazynowy poemat, a później Srebrne i czarne wzbudzały powszechny entuzjazm, choć te dwa tomiki razem liczyły zaledwie kilkanaście wierszy, ale sięgały szczytów twórczości literackiej. Słychać było w strofach tych poematów szum skrzydeł geniuszu poetyckiego ${ }^{3}$.

Dwudziestoletni Lechoń pisał inaczej, niż można by się było spodziewać po kimś młodym, odstawał od współtworzonego przez siebie Skamandra piórem i wyglądem. Już wówczas, w latach międzywojennych, w meloniku i fraku starszego pana wywoływal w Warszawie sensację. Był jednocześnie anachronistą i prekursorem. Obracał się $\mathrm{w}$ towarzystwie największych intelektualistów, był uczestnikiem wszystkich ważniejszych wydarzeń kulturalno-literackich lub ich inicjatorem. Uwielbial kostium, ceremonię i pompę, każdy dzień starał się reżyserować niczym teatralną galę. Supremacji Lechonia poddawali się nawet o wiele starsi koledzy „od pióra”. Jego poetyka nie mieściła się w obowiązującej konwencji literackiej Polski międzywojennej, ale po 1939 roku brzmiała wyraziście i celnie jak nigdy przedtem. Lechoń cyzelował każde słowo z iście benedyktyńską cierpliwością i dokładnością, wczuwał się w przeszłość jak nikt z jego równieśników, wszystko, co związane było z ojczyzną, przeżywał i odczuwał bardzo głęboko, wykazując związki między tradycją historyczną, a współczesnymi losami narodu. Podobnie jak w życiu prywatnym, także w poezji sięgał często po kostium,

${ }^{2}$ J. Lechoń, Dziennik, oprac. R. Loth, t. 1, Warszawa 1992, s. 527. Zapis z 5 września 1952 roku.

${ }^{3}$ L. H. Morstin, Jan Lechoń, [w:] Pamięci Jana Lechonia, Londyn 1958, s. 75. 
lubując się w klasycznych chwytach, w nawiązaniach do wielkiej historii i biografii wielkich ludzi, całymi garściami czerpiąc z tradycji romantyzmu. Wydawało się, że nie widział życia realnego, we wszystko angażował się całą swą mocą, nie znosząc sprzeciwu, tworząc sytuacje skrajne i napięte.

Charakterystyczny i paradoksalny w odniesieniu do Lechonia jest fakt jego duchowej samotności, której doświadczał w dzieciństwie i potem już przez całe życie, nawet w tych okresach, gdy był bardzo blisko ludzi. Zbigniew Czermański konstatował:

$\mathrm{Z}$ tą samotnością było mu dobrze i źle, tak samo jak ze sławą. Spadła na niego wcześnie, ucieszyła, ale też na resztę życia pozbawiła spokoju ${ }^{4}$.

\section{Lechoń komentował to w następujący sposób:}

Trzydzieści pięć lat mego życia płynęło w nurcie ważnych wypadków, znałem wszystkich prawie ludzi, którzy w tym czasie byli czymś w Polsce, a później w Paryżu. I wszystko to — nigdzie się nie utrwaliło, leży bez ładu w mej, pewno coraz gorszej pamięci. Dzisiaj jestem pustelnikiem, zamkniętym i z konieczności, i z własnej filozofii w ciemnym West Sides.

Przedwcześnie dojrzały i obarczony brzemieniem bardzo młodego debiutu Lechoń najpierw usiłował udźwignąć sławę, a potem podsycać jej blask. Wszystkie myśli i działania poety skupione były wokół pragnienia pisania co najmniej tak dobrze, jak w Karmazynowym poemacie. Przestoje w tworzeniu wzmagały jego neurastenię i myśli samobójcze. Nawet w okresie płodnym pisarsko, w 1921 roku, Lechoń próbował targnąć się na swoje życie, co może świadczyć między innymi o tym, że nie był w stanie unieść sławy i presji własnej oraz otoczenia. Co znamienne, młody Lechoń żył sprawami, do których większość jego równieśników nie dorosła, dojrzał przedwcześnie, jego dziecięce zabawy skupiały się wokół literatury i historii, można by do niego odnieść stwierdzenie z Księgi Mądrości, iż „wcześnie osiagną̧wszy doskonałość, przeżył czasów wiele”. Dojrzały Lechoń natomiast z uporem powracał do przeszłości. Stany uporczywej melancholii potęgowane były statusem emigranta i uchodźcy, który miał przez ostatnie ćwierć wieku życia.

Warto przyjrzyjeć się dysharmonii wewnętrznej Lechonia, rozdartego między umiłowaniem życia, a widmem totalnego zniszczenia, któremu podlegał „od zawsze”. Lechoń wielokrotnie zauważał podobieństwo między tym, co odczuwał w młodości, a stanami ducha człowieka dojrzałego:

Przez ostatnie lata myślałem, że już nie będę nigdy taki, jak jestem teraz — to znaczy, że nie będę się czuł tak jak przed trzydziestu laty. I jestem znów zagubiony, sam i przekonany, że poza pisaniem nie istnieję i nie warto, żebym istniał'.

${ }^{4}$ Z. Czermański, O Leszku, [w:] Pamięci Jana Lechonia, s. 133.

${ }^{5}$ J. Lechoń, Dziennik, s. 100-101. Zapis z 27 października 1949 roku.

${ }^{6} \mathrm{Mdr}$ (4, 13).

${ }^{7}$ O melancholii Lechonia zob. szerzej w: J. Kisielowa, Retoryka $i$ melancholia. O poezji Jana Lechonia, Katowice 2001.

${ }^{8}$ J. Lechoń, Dziennik, s. 84. Zapis z 15 października 1949 roku. 
Przy okazji świętowania nowego roku lub urodzin Lechoń zastanawiał się zwykle, czy zasłużył już sobie na dobry nekrolog. Gdy zapomniał o czymś ważnym, tłumaczył to ,,dolegliwościami po pięćdziesiątce”. Już jako czterdziestolatek zwykł stawać przed lustrem, by odnaleźć oznaki nieubłaganego starzenia się. Stawanie przed lustrem było jednak w przypadku Lechonia bardzo symboliczne, gdyż nie dotyczyło jedynie upatrywania na sobie znamion upływu czasu, wiązało się także z nieustającymi rachunkami sumienia, rozliczniem się z przeszłości oraz z wypełnionych powinności („Rozsądziłem sam siebie i jak Edyp oczy / Wyrywam z siebie serce rękami własnymi”'; „Ach! ileż jest spoczynku w tym słowie: tak trzeba!"10). Lechoń zdawał sobie sprawę, że gonienie za doskonałością jest w gruncie rzeczy wielkim komedianctwem i że człowiek dażący do doskonałości zawsze stoi przed lustrem. Jego pięćdziesiąte drugie urodziny stały się okazją do refleksji, że Mickiewicz ${ }^{11} \mathrm{w}$ tym wieku napisał już wszystko i był u schyłku życia.

Trudno zrozumieć, że Lechoń miał przez całe życie problemy z określeniem swojej pisarskiej tożsamości, identyfikując się niemal jedynie w oparciu o porównania z wielkimi pisarzami i przedstawicielami kultury, głównie romantyzmu:

Prześladuje mnie myśl zarazem megalomańska i pełna pokory, że mogłem być tak wielkim poetą — jak... nie powiem kto, ale na to powinienem był inaczej zupełnie urządzić się w życiu [...]. A poza tym trzeba było nie myśleć ciągle: „,To już napisano, to już Mickiewicz zrobił lepiej ode mnie” — tylko pisać tak, jakby nikt przede mną niczego nie napisał. W rezultacie znaczy to, że trzeba by się było urodzić po raz drugi i nie sobą. Czyli że nie ma co biedać, bo nie mogłem przecież nie być sobą. A swoją drogą — szkoda ${ }^{12}$.

Lechoń postrzegał siebie jako twórcę anachronicznego, czemu dał wyraz w wierszu Poeta niemodny:

Mówią mi: ,Nic nie wskrzesi czasu co przeżyty,

Wkrótce i o nim pamięć wśród młodych się zatrze.

Zabieraj ze sobą swoje stare rekwizyty,

Bo nową będą grali sztukę w teatrze"13.

Z początkiem 1951 roku Lechoń zanotował informację o trzecim już pogrzebie w tym samym kościele w ciągu sześciu tygodni:

\footnotetext{
${ }^{9}$ Tenże, Oediupus rex, [w:] tenże, Poezje, s. 185.

${ }^{10}$ Tenże, Toast, s. 30.

${ }^{11}$ Podziw dla Mickiewicza był dla Lechonia czymś niemalże mistycznym i religijnym, urastał do miana kultu, do tego stopnia, że Lechoń zatracił obiektywizm, budując wieszczowi potężny ołtarz: ,,Mickiewicz był mistrzem muzyki polskiej mowy, był Bachem jej tajemniczej pięciolinii, zdolnym jak on zestroić dźwięki w zespoły o idealnej zarazem prostocie i mądrości”. Zob. J. Lechoń, O literaturze polskiej, Warszawa 1993, s. $118 \mathrm{i}$ in.

${ }^{12}$ Tamże, t. 3, s. 527 . Zapis z 19 października 1954 roku. W listach do M. Grydzewskiego, pochodzących ze stycznia 1951 r., Lechoń natarczywie pytał adresata, czy ma talent, czy podobają mu się jego teksty. Zob. Mieczystaw Grydzewski, Jan Lechoń, Listy 1923-1956, z autografu do druku przygotowała, wstępem i przypisami opatrzyła B. Dorosz, Warszawa 2006, s. 382-383.

${ }^{13}$ J. Lechoń, Poeta niemodny, [w:] tenże, Poezje, s. 198.
} 
Jest w tym coś tragicznie groteskowego, jakbyśmy chowali tego samego człowieka. Bo też i chowamy go. Owego symbolicznego, ,nieznanego wygnańca”, który umiera z tęsknoty i niemożności oddychania w obcym świecie ${ }^{14}$.

Poety nie opuszczały stany smutku i trudnej do zdefiniowania melancholii, czuł się bardzo samotny:

Z czasów, gdy miałem prawdziwy rozstrój nerwów, wiem, że nic nie zapominamy, że wszystko jest złożone w naszej pamięci, nawet w naszym sercu — bo płakałem z rozpaczy po rzeczach straconych przed wielu laty ${ }^{15}$.

Lechoń chwilami dźwigał się z pesymizmu, zwykle po to, by usiąść do pisania, przygotować jakieś wydarzenie kulturalne dla francuskiej czy amerykańskiej Polonii, starał się zerwać z tym, co w nim umarło i ,leży jak trup, zajmując miejsce potrzebne nowości”:

Starość - co tu gadać, starość ciała beznadziejna — bo przecież nie będę nosił tupetu ani gorsetu — a dość, bym spojrzał na moje dzisiejsze fotografie, aby stwierdzić ze złością, żem już dojrzał do mego zawsze starczego głosu. Gadam o tej starości z nieświadomej kokieterii od paru lat i trzeba z tym skończyć, bo ludzie znudzeni wreszcie powiedzą: „,Masz rację. I nie zawracaj nam głowy”. I teraz akurat chcę pisać, utrwalać, zastanawiać, gdy te godziny wysiłku myśli już mnie nie męczą. Żyję pociechą, że teraz dopiero to wszystko się we mnie ,,ucukrowalo, uleżało”, że więc niczegom nie zgubił, niczego nie zaniedbał — że to tylko druga i późna pisarska młodość. Ale nawet jeśli w tym jest dużo prawdy — to nie cała ${ }^{16}$.

Nie cała prawda, gdyż chwilę później Lechoń notował o obsesji starości, która odchodzi na parę godzin i znów powraca oraz o atakach przeraźliwego smutku związanego z tym, że nie przygotował się do starości i nie wie, „,co zrobić bez młodości”. Lechoń ulegał wrażeniu jakoby życie toczyło się obok niego. Chwytał się więc nadziei i liczył na cud, ,,że odkwitnie”, ,,nadziei tak bezsensownej jak moje dziecinne modlitwy »żebyśmy nigdy nie umierali«"17.

Dystans człowieka dojrzałego, wtajemniczonego w to, co zbiorowości ludzkiej niedostępne, zachowującego klasyczny dystans artysty do tragicznych zdarzeń widać również w poezji Lechonia:

My z starym Sofoklesem spokojnie patrzymy

$\mathrm{Na}$ ten widok, na który chciałbyś zamknąć oczy ${ }^{18}$.

Sprawą pierwszej wagi było dla Lechonia zachowanie twarzy przed ludźmi, nawet wobec największych dramatów i burz życiowych:

\footnotetext{
${ }^{14}$ J. Lechoń, Dziennik, s. 119. Zapis z 5 maja 1951 roku.

${ }^{15}$ Tamże, s. 299. Zapis z 26 listopada 1951 roku.

${ }^{16}$ Tamże, t. 3, s. 390. Zapis z 10 maja 1954 roku.

${ }^{17}$ Tamże, s. 662. Zapis z 16 lipca 1955 roku.

${ }^{18}$ J. Lechoń, [*** Od żalu nie uciekniesz, nie ujdziesz goryczy...], [w:] tenże, Poezje, s. 63.
} 
Wszystko na oczach ludzi, lecz wszystko w milczeniu.

Choć wszystkie razem brzękły gitary Grenady,

Ja jeden w czarnym płaszczu przechodziłem blady

I wśród masek tańczących szedłem w gaj oliwny,

Słysząc tylko za sobą: „Co za człowiek dziwny!”

Patrząc w lustro na twarz swą, zrytą wieczną troską,

Ten człowiek mówił sobie: „,Milcz, na miłość boską,

$[\ldots]^{19}$.

Wokoło tylko trwogi i troski tak liczne,

Ale ty się nie buntuj przeciw przeznaczeniu:

Spokojnie pisz do końca swe wiersze klasyczne,

Które wtedy sa dobre, gdy cierpisz w milczeniu ${ }^{20}$.

Milczenie godne Sofoklesa stało się niemal programem życia Lechonia, wierzącego w zrządzenia losu, fortuny, gwiazd i Opatrzności, którym człowiek podlega. Zarówno w doniosłych, jak i codziennych zdarzeniach dopatrywał się on wpływu gwiazd, całkiem serio traktując horoskopy i rozmowy z parającą się ezoteryką przyjaciółką —Zofią Kochańską. Z godną podziwu i szacunku wytrwałością pragnął Lechoń donieść do końca krzyż swoich ciepień i demonów wewnętrzych, a także, symbolicznie, brzemię całej udręczonej ludzkości:

Kielichy wznieśmy w górę i pijmy na stypie,

Bo żal nasz byłby śmieszny, a skarga daremna.

Niech nas trupio spokojnych pochłonie noc ciemna,

A łopata grabarza milczących zasypie ${ }^{21}$.

Podmiot mówiący wierszy Lechonia wielokrotnie uświadamia sobie, że wszystko skończone:

Pojąłem, że to prawda, że wszystko skończone ${ }^{22}$.

Nic jeszcze nie chcę żegnać, lecz już widzę świetnie

To wszystko, co stracone i co niedościgłe ${ }^{23}$.

Stracone, choćby jeszcze dni przyszły łaskawsze,

Pogrzebane, stracone, stracone na zawsze ${ }^{24}$.

By zobrazować podobieństwo stanów psychicznych poety debiutującego i będacego u schyłku życia przyjrzyjmy się dwóm lirykom. Pierwszy, zatytułowany Jan Potocki

\footnotetext{
${ }^{19}$ Tenże, Erynie, s. 190.

${ }^{20}$ Tenże, Jabłka i astry, s. 97.

${ }^{21}$ Tenże, Toast, s.30.

${ }^{22}$ Tenże, Wieczór w Salamance, s. 79.

${ }^{23}$ Tenże, Stara Warszawa, s. 114.

${ }^{24}$ Tenże, Erynie, s. 189.
} 
miał pierwodruk w 1921 roku, drugi, o incypicie [ ${ }^{* *}$ Choratu Bacha styszę dźwięki] ukazał się na emigracji, trzydzieści jednen lat później:

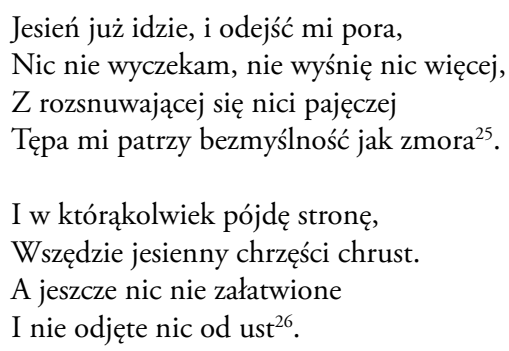

Jak widać, przez cały okres twórczy poezja Lechonia wypełniona była nieokreśloną stratą. Poeta zachowywał pozory integralności świata - patetycznego, swoją monumentalność opierającego na dorobku kultury. Są to jedynie pozory, bowiem w rzeczywistości podmiot mówiący w wierszach, będący porte-parole autora, żył odległymi, utopijnymi wizjami i jeśli uczestniczył w realnie toczącym się życiu, to tylko w takim wymiarze, w jakim życie to dotyczyło spraw kultury, meblowania emigranckiego życia polskością, jej sprawami, jej kulturą, jej wielkością, jej chwałą.

Wiersze z okresu nowojorskiego często skupione były tematycznie wokół wspomnień z Warszawy dzieciństwa. W poezji tej pojawiali się rodzice Lechonia, jego przyjaciele ze szkolnej ławy, warszawskie ulice i domy, polskie wiosny, jesienie i zimy, polska przyroda ${ }^{27}$. Wspominanie tego etapu życia bywało bolesne, ale najczęściej były to dla Lechonia momenty wewnętrznego wytchnienia, zupełnie jakby świat wyobraźni urealnił się na chwilę. Z kolei małe, ale bolesne straty, którymi naznaczone jest życie, przywoływały na myśl nieuniknioną stratę ostateczną:

\footnotetext{
Nic nie ma prócz tych liści, co na drzewach zmarły,

Nic nie ma prócz tych wichrów, którymi przewiało,

Nic prócz śladów świetności, co się już zatarły,

Nic się nie stanie więcej, już wszystko się stało ${ }^{28}$.
}

Ach! I sąd jeszcze Ostateczny,

Na który trzeba będzie iść ${ }^{29}$.

Tracenie pozwala zdobyć życiową mądrość, spojrzeć oczami człowieka doświadczonego i dojrzałego, pokazuje, co istotne i ponadczasowe. Sięgając do kultury klasycznej, Lechoń wskazywałe na ponadczasowy sens życia i istnienia:

\footnotetext{
${ }^{25}$ Tenże, Jan Potocki, s. 165.

${ }^{26}$ Tenże, [ ${ }^{* * *}$ Choratu Bacha styszę dżwięki], s. 125.

${ }^{27}$ Zob. wiersze Stara Warszawa, Hymn Polaków z zagranicy, Kolęda, Męczennicy, Mokotowska piętnaście, Ojców i inne.

${ }^{28}$ J. Lechon', Toast, s. 30.

${ }^{29}$ Tenże, [**Chorału Bacha styszę dżwięki], s. 125.
} 
Z odmętu niepamięci jakiś powiew żenie

Dźwięk słów na pozór błahych jak pożółkłe wstążki,

Których teraz dopiero rozumiesz znaczenie,

Jak za wcześnie czytanej bardzo mądrej książki ${ }^{30}$.

Szukając siebie w totalnym wewnętrzym rozbiciu (na przykład w wierszu św. Antoni), dokonał Lechoń aktu samopoznania i zawierzenia Bogu, wzywanemu szczególnie gorliwie w tych sytuacjach, gdy odnosił wrażenie, że nie mógł umknąć przed destrukcyjną mocą Erynii - tych samych, które znał z dzieciństwa:

Pod ogrodu drzwiami stajecie, Erynie!

To mojego dzieciństwa jarzębiny krwiste ${ }^{31}$.

Pod koniec życia podmiot mówiący patrzył wstecz z dwóch perspektyw. Pierwsza przybliżała utracone obrazy, intensyfikowałą je, sprawiała, że nabierała głębi i zdała się ożywać, druga, należąca do człowieka wewnętrznie zbolałego, ukazała przeszłość z daleka, jakby przez mgłę:

Co kiedyś twe spojrzenie muskało przelotnie,

Tym dzisiaj się napieścić nie może twe oko,

Te same mógłbyś kwiaty oglądać stokrotnie

I zieleń, co wciąż bardziej zda ci się głębokąą

Jak przez mgłę widzę tylko z coraz większej dali

Te, którem niegdyś kochał, które mnie kochały ${ }^{33}$.

W połowie XX stulecia w literaturze coraz silniej utrwalali się reprezentanci nowego pokolenia, tacy jak Czesław Miłosz czy Witold Gombrowicz. Zwłaszcza na pierwszego kierował Lechoń ostrze zajadłej krytyki. W swym diariuszu wielokrotnie wypowiadał się o nim jako o talencie trzeciej klasy ${ }^{34}$. Podobną niechęcią darzył pisarstwo Gombrowicza. Ferdydurke pozostała przez Lechonia zupełnie niezrozumiana i zepitetowana jako ksiażka infantylna:

W Ferdydurke Gombrowicza jest bardzo zasadniczy element poważnego pisarstwa. Wysiłek stworzenia własnego stylu. Niestety! Autor nie przezwycięża swego infantylizmu przez to, że go sobie nie uświadamia. Jest to nie tylko ksiażka o infantyliźmie. Ale również książka infantylna”35.

Twórcy wyznaczający kierunek współczesności literackiej byli przez Lechonia poddawani druzgocącej, pogardliwej krytyce, wynikającej najprawdopodobniej z poczucia

\footnotetext{
${ }^{30}$ Tenże, Jabtka i astry, s. 96.

${ }^{31}$ Tenże, Erynie, s. 188

${ }^{32}$ Tenże, Jabtka i astry, s. 96

${ }^{33}$ Tenże, Plato, s. 130.

${ }^{34}$ J. Lechoń, Dziennik, t. 3, s. 218. Zapis z 28 września 1953 roku.

${ }_{35}$ Tamże, t. 1, s. 320. Zapis z 22 grudnia 1951 roku.
} 
znalezienia się na literackim marginesie, nieuniknionego, w efekcie trwającego czterdzieści lat „,konserwowania” własnej twórczości i osobowiści w obszarze narodowej martyrologii. Dawniej to Lechoń wyznaczał kierunek życia literackiego, w nowej literackiej konstelacji nie odnajdywał już dla siebie miejsca. W tym kontekście refleksja Gombrowicza zdaje się trafiać w samo sedno Lechoniowego sukcesu i dramatycznej jego porażki:

[...] Co gorzej, poeta ten, zabarykadowany w wieży klasycyzmu [...] stracił zupełnie wyczucie człowieka współczesnego i jego problematyki (o której notabene niewiele mu było wiadomo, gdyz drogi myślenia ludzkiego poczawszy od Hegla były tej głowie polskiej prawie nieznane). [...] Przemykał się bokiem. Wykręcal się i nadrabiał miną. W pewnej chwili znalazł się zupełnia poza nawiasem. Cała jego polityka polegała na puszczaniu w świat, w dłuższych odstępach czasu jakiegoś .»pięknego« wiersza, aby nie mówiono zbyt głośno, że się skończył oraz na pielęgnowaniu swych towarzyskich prestizów, w czym jego kultura, inteligencja i dowcip bardzo były mu pomocne. [...] Tak to Lechoń próbowal jeszcze udawać, że żyje, restaurując sobie świat umarły, ten z pierwszej młodości, z czasów, które potraktowały go łaskawiej [...]”36.

Wewnętrzne rozdarcie Lechonia, balansującego między wspomnieniami z młodości, a poczuciem przegranej i przerażliwym pragnieniem śmierci, było jego rysem charakterystycznym, ujawniającym się przez całe życie. Przedwczesna dojrzałość i tragiczna śmierć zdawały się być mu pisane, a każdy przeżyty przez niego rok uznać można za czasowe jedynie odroczenie przeznaczenia. Duży to ciężar dla dziecka spojrzeć Eryniom w oczy. Duży to ciężar dla młodzieńca udźwignąć brzemię geniuszu poetyckiego. Duży to ciężar dla człowieka dojrzałego sprostać zadaniu poetyckiego rządu dusz, które okazało się być nie do udźwigniecia. I to na obcej ziemi.

Monika Urbańska

“I LOOK AT THE DESTRUCTION, WHAT CROP, BUT AFTER ALL, NOTHING IN MY HEART DIDN`T GO TO WASTE” — Poetic Flashbacks of Jan Lechoń

Summary

First volume of Jan Lechon poetry appears in print when he was 13. It surprises its maturity and depth. The young poet reached the common motives of decadent sadness and doubt, but spiritual loneliness, interest of existential themes were not typical for teenager.

Karmazynowy poemat was received as a literary revelation. Lechon reaches literary perfection as a young man, so all the adult life he efforts to remain poetic laurel.

As a mature creator he glanced at his reflection in the mirror, not only to seek the passage of himself, but also to examine his conscience to settle with the past. At the end of his life, Lechon was convinced "it is all over". His poems from this period says about longing for the lost homeland. Inner conflict of poet balancing between memories of his youth and terrifying death wish was his characteristics lifelong feature. Premature maturity and tragic death seemed to be his destiny - each lived year of Lechońs life can be considered as a temporary postponement of death heppened to him on New York pavement on tragic Friday afternoon in June 1956.

Słowa kluczowe: literatura XX wieku, poezja, emigracja, melancholia

Keywords: Literature of $20^{\text {th }}$ century, poetry, emigration, melancholy

${ }^{36}$ W. Gombrowicz, Dziennik (1957-1961), Paryż 1971, s. 155. 